Article

\title{
A Multi-Criteria Decision-Making Model to Choose the Best Option for Sustainable Construction Management
}

\author{
Seyit Ali Erdogan ${ }^{1}$, Jonas Šaparauskas ${ }^{1}, * \mathbb{C}$ and Zenonas Turskis ${ }^{2}$ (D) \\ 1 Department of Construction Management and Real Estate, Faculty of Civil Engineering, Vilnius Gediminas \\ Technical University, Saulètekio al. 11, LT-10223 Vilnius, Lithuania; ali_erdogan1907@hotmail.com \\ 2 Laboratory of Operational Research, Institute of Sustainable Construction, Faculty of Civil Engineering, \\ Vilnius Gediminas Technical University, Saulètekio al. 11, LT-10223 Vilnius, Lithuania; \\ zenonas.turskis@vgtu.lt \\ * Correspondence: jonas.saparauskas@vgtu.lt; Tel.: +370-5-274-52-45
}

Received: 22 February 2019; Accepted: 10 April 2019; Published: 14 April 2019

\begin{abstract}
The article briefly discusses the content and terms of construction project management. It identifies the main problems of construction management and discusses ways to solve those using multi-criteria methods. Well-performed management is one of the critical factors which leads to the success of any significant sustainable project. Construction project management consists of setting goals and defining user requirements, project constraints, and resources needed. This paper aims to create a practically useful model. The paper presents a comprehensive set of criteria, which led to the creation of a decision-making model for construction management, which was applied to a Turkish case study. The Analytic Hierarchy Process (AHP) method and the Expert Choice computer program were used for calculations.
\end{abstract}

Keywords: project; construction; contractor; multiple-criteria decision-making; AHP; sustainable solution; choice; expert

\section{Introduction}

Two-thirds of the world's people believe that global warming is the most critical environmental problem in the world. Increasing the impact of construction information has a positive impact on stakeholders' interests and encourages sustainable construction [1]. Given the balanced implementation of ecological, economic, and social needs in the implementation of projects, there is a need to integrate the principle of sustainability into project management practices and the academic community. Creation and management of a healthy artificial environment based on ecological resources and design efficiency is the goal of contemporary construction. Modern construction emphasizes the need to integrate stability into project planning, management, evaluation, and decision-making to improve project quality and value. Planning and the successful implementation of the project directly affect the goals of constant construction. Therefore, continuous project planning reflects project planning methods for economic, social, and environmental sustainability. Systematic approaches, the views of all stakeholders, knowledge, and expertise in implementing a sustainable development project and their ability to apply them properly are critical factors for the success of sustainable construction. Project planning is a well-known theoretical concept in the literature on project management. However, we know little about how much effort is needed to invest in the project planning phase to ensure efficient and systematic project management and to evaluate the planning of the current project. According to existing research, management of permanent projects involves both internal and external perspectives. The essential aspects related to project management are the project life cycle requirements. 
The control of external perspectives deals with the life cycle of the product and focuses on planning, implementation, and further support management and processes. The construction project solves stability problems based on ecological, economic, and economic reasons and the life cycle of the project's resources.

There are seven key principles of a building's life cycle in sustainable construction: less resources used, resource reuse, use of recyclable resources, reduction or elimination of negative impacts on the environment, non-use of toxic materials, reduction in the costs of the building's life, and the project's life cycle quality.

Sustainable design is a design philosophy that aims to maximize the artificial environment by reducing or eliminating negative environmental impacts. Building green buildings means improving the efficiency of buildings to use energy, water, and materials efficiently and minimize the negative effects on human health. It means that project managers will be responsible for managing more complex budgets and projects. A green building is carefully designed, built, operated, and reused, or removed from the artificial environment, in an environmentally friendly, energy-efficient, and stable manner. The best location, design, construction, operation, service, and removal (part of the building's life cycle) are the means to achieve this.

The building construction sector is a complex industry. It has a long-lasting impact on the economy, the environment, and society, and requires much investment. Construction management and technology are two critical factors influencing the construction industry. Poor execution of construction projects, taking into account costs and planning, is one of common problems. Over the past three decades, designers and architects have applied dozens of efficient and effective advanced building technologies and engineering innovations to construction projects.

Nevertheless, the overall efficiency of the sector is quite low [2]. Prior practice has shown that digital technology allows flexible and efficient planning, management, and implementation of construction projects [3]. Successful implementation and results of new techniques and technologies depend on the active participation of project management specialists interested in implementing them, the information available to the population concerned about the project, and effective management of the project. Effective project management aims to achieve project goals by applying knowledge, skills, and estimation tools, overall organization, planning and control techniques in such way that the results meet the requirements of acceptable quality, risk, security, and safety levels, and ensures timely implementation of the project with the efficient use of funds [4]. Therefore, sustainability is an essential part of project management.

Sarma [5] described the three main groups of effective management process (Figure 1). Confucius said [6]: "In all things, success depends on previous preparation, and without such previous preparation there is sure to be the failure." The project character changes in each life cycle phase (Project Origination $\rightarrow$ Project Initiation $\rightarrow$ Project Planning $\rightarrow$ Project Execution and Control $\rightarrow$ Project Closeout $\rightarrow$ Post-Project Evaluation). In each stage of the project life cycle, new intermediate products are created, with the critical outcome of one phase forming an essential input to the next step. Each project's control system should include costs, planning and scheduling activities, and a change management control. Construction projects of different types of buildings impact the project life cycle and management options. Figure 2 shows a pyramid (hierarchy) of different available approaches, which are applied to select the proper project option. 


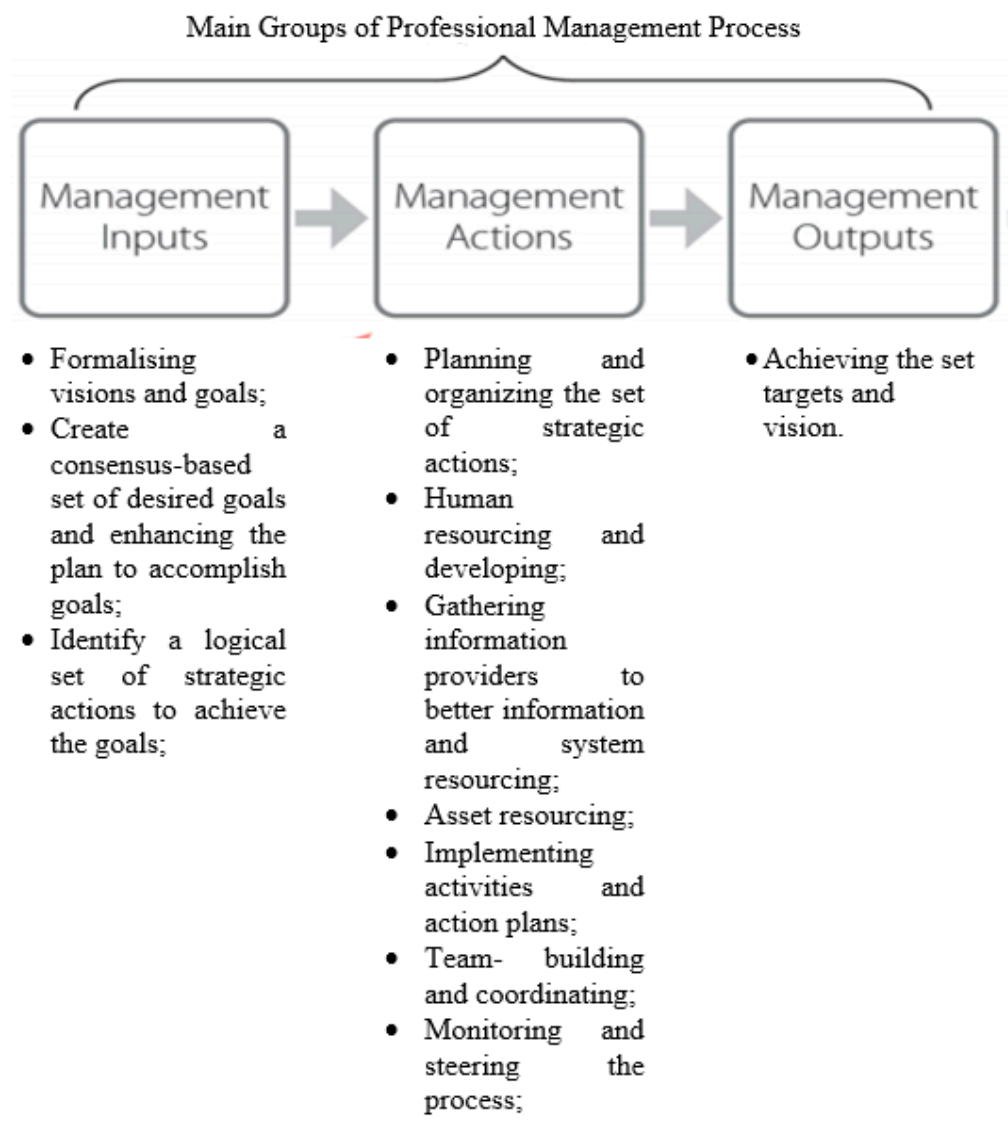

Figure 1. Main groups of professional management processes.

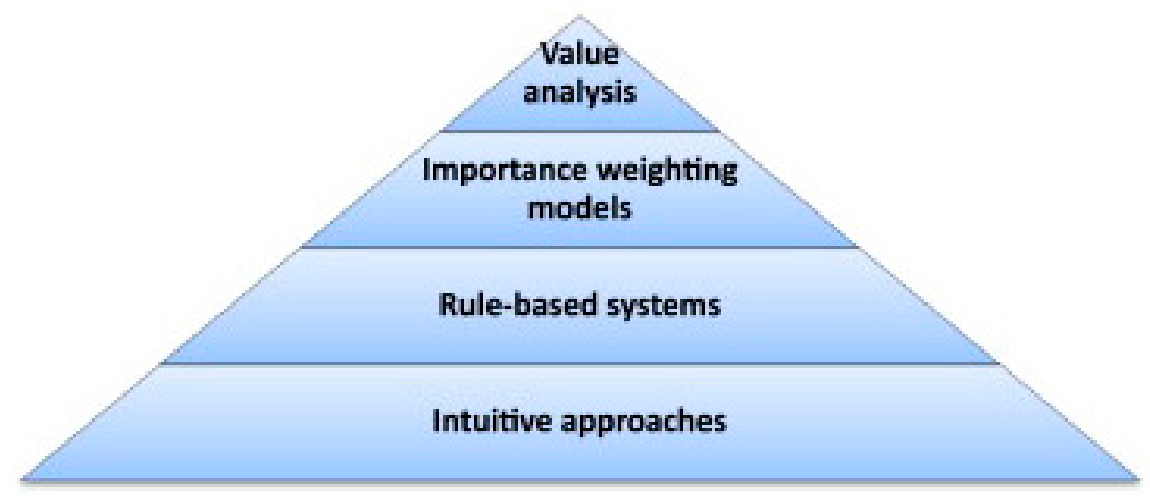

Figure 2. A pyramid of decision approaches [7].

The aim of the article is to identify the main problems in construction management; to develop a model (framework) for decision-making; to present a case study analysis; and to make conclusions.

\section{Problems of Construction Management}

A successful construction organization does not consider itself to be a producer of goods or services but is looking for ways to buy a customer who wants to do business with it [8,9]. Dickson [10] identified selection criteria, which profoundly influenced later research in this area. The dynamics of the contractor selection studies built on innovation that moved toward the achievements of different fields of sciences. The different motivations of the persons involved were separated into task-related and non-task-related goals [11].

The idea of sustainability was born in the 18th century and applied to forest management issues (von Carlowitz, 1713, in Reference [12]). Options' evaluation and selection of the best contractor 
are critical issues to reduce financial costs and improve competitiveness in the temporary market. Moreover, environmental requirements and evaluating the potential contractors by incorporating green factors into the selection process are additional concerns. Yazdani et al. [13] presented an approach addressed to the inter-relationships between the customer requirements with the Decision Making Trial and Evaluation Laboratory (DEMATEL) method, while constructing a relationship structure. Finally, the Technique for Order Preference by Similarity to an Ideal Solution (COPRAS) was applied to prioritize and rank the alternatives. Kamali et al. [14] stressed the importance of choosing the right contractor approach between different options. Therefore, it is necessary to evaluate potential contractors according to many criteria, including aspects related to the different stages of the life cycle of a building. The most critical step is to identify and select the right set of criteria and their weightings. Besides, the results have shown that a focus on the social aspect of sustainability is increasing compared to environmental aspects.

In the last thirty years, maintainable progress has extensively expanded its acknowledgement between policy- and decision-makers. Nowadays, this notion objects to delivering a better setting, a more advanced society, and a settled economy in both developed and developing countries. Consequently, in order to reach a sustainable society, you essentially comprehend the basic gauges and espouse suitable sustainable policies in dissimilar parts of society and its subdivisions. As a vibrant element, the construction industry plays a critical role in sustainable growth, which appeals to decision-makers to discover sustainable solutions globally for such an active sector.

Heravi et al. [15] established a two-stage context to ponder uncertainty together with numerous fondness orders and peril attitudes of decision-makers via efficacy functions. The primary step takes advantage of the incorporation of the efficacy function, ELECTRE I (the elimination and choice translating reality), and Grey theory to rank the practicable substitutes. The next step utilizes the ordered weighted averaging (OWA) hand to aggregate the predilections of environmental, public, and economic measurements as three decision-makers, to determine the concluding ranking.

Rashid et al. [16] showed a tentative and analytical inquiry to advance a sustainably castoff concrete by combining ceramic waste as coarse aggregate. Ecological influences were also well thought out regarding the $\mathrm{CO}_{2}$ footprint and the consumption of raw materials by concrete. They used the analytical hierarchy process (AHP) and Method for Order Preference by Resemblance to the Ideal Solution (TOPSIS).

Infrastructure is the main driver that can accelerate the equilibrium among the financial, public, and ecological features forming the triple bottom line. Diaz-Sarachaga et al. [17] regarded a methodology for the advance of a sustainable infrastructure rating system (SIRSDEC) targeted at encouraging the design, construction, and processing of sustainable infrastructure ventures in these geographical areas. The SIRSDEC was designed into an ordered decision-making tree involving three stages of essentials (requirements, criteria, and indicators) selected to measure infrastructure systems rendering to sustainability principles. The methodology of the SIRSDEC integrates the act of Multiple Criteria Decision Making (MCDM) methods such as the AHP to weight the essentials forming the decision-making tree and the integrated value model for sustainable assessment (MIVES) to value infrastructure projects according to their involvement at the triple bottom line.

The top issue in sustainable projects is the collection of a suitable contractor and construction technique, and they are the conclusive factors for their achievement. Ecological consequences are closely joined with society's built-in uncertainties and perils, and they are uncertain since environmental systems, as well as social systems, will undergo changes in the upcoming years. Therefore, the appointment of an appropriate contractor and a suitable construction method is an MCDM issue vastly important and must operate with fractional knowledge and uncertainty. Bansal et al. [18] implemented a fuzzy synthetic evaluation method using the analytic hierarchy method to deliver an analytical instrument to assess the applicability of prefabricated or on-site construction techniques.

Decision-makers' MCDM model is progressively used to explain sustainable construction matters [19]. Only one out of ten of the reviewed papers are measured comprehensively with 
limited inadequacies. An MCDM is a decision-making tool applied to an extensive range of ecological supervision difficulties. A thrilling ground of submission of the MCDM model is the assessment and analysis of the diverse features when numerous stakeholders are involved.

Fuzzy and hybrid approaches have been progressively used in construction risk management research. Islam et al. [20] accumulated and analyzed the basic perceptions and methods applied in this area to date. They suggested that the nature of compound projects is such that most risks are symbiotic of each other. Consequently, a fuzzy structured method such as the fuzzy analytical network process (FANP) has commonly been used for unlike compound projects.

Diaz-Balteiro et al. (2017) [21] analyzed and measured 271 papers in the Web of Science database linked to discrete MCDM and sustainability. There were three methods that were most commonly used: AHP, TOPSIS, and Simple Additive Weighting (SAW). A noteworthy part of the MCDM techniques were the hybridized with cluster decision-making techniques, which have been applied to a countless variety of problems, levels, and segments related to sustainability. The purpose of this hybridization procedure entails including in the analysis the likings of the stakeholders concerning the indicators originally recommended. The appearance of new auspicious approaches like the uneven set theory hybridized with MCDM is of interest. The difference between ordinal and fundamental preferences, whole and fractional preferences, or local and universal preferences, leads to different situations that describe precise group decision-making models.

Having the ability to set a winning direction within the sustainable development of the environment and motivating people to follow that direction is the most exciting aspect of the construction industry. Each of the methods for contractor selection has some limitations, depending upon how each is used [22].

Many researchers have highlighted the quality of delivery and products as the primary factor in choosing suppliers [23-25]. One can understand the life cycle of construction projects as a process that involves risks. Contractual risk management is an integral part of effective legal risk management. The contractual risk management objectives do not limit the management of legal risks associated with the conclusion of contracts. Integrated contractual planning and management, as well as contractual risk management approaches, are similar to other risk management measures in the economy [26,27].

There is not one single management mode for managing each different project. The implementation requirements for various projects do not precisely match the needs of other projects.

All construction professionals, such as civil, mechanical, and electrical engineers, financiers, and architects, have a significant impact on the entire construction process. They affect both situations, people's choice and management, goals, efficiency, and quality. The building is classified as a construction project when the planning of the construction is complete. Tenders select contractors through contests from potential and qualified contractors. The contractor is selected using one of three common selection methods: qualification-based selection, selection according to the best-value selection, or low-bid selection. Today's project manager is confronted with many old or new challenges. Many of these challenges directly affect construction performance, while others have an indirect impact on peripheral activities. Implementation of a construction project is an integration of complex interrelated activities for achieving the objectives set, which is the best-organized disorder.

The primary features of the implementation of construction projects:

(a) The work is not carried out under controlled conditions, and therefore is highly dependent on weather conditions and other environmental conditions [28];

(b) The information for a specific building site varies significantly depending on the size and importance of the designed building, its location, and whether the facilities to be provided are in an unmapped area or merely an expansion of the existing facilities [29];

(c) Construction processes depend on the knowledge and abilities of the planners;

(d) Safety: construction by nature is inherently dangerous, with a high degree of hazard and risk; 
(e) The threat has to be transferred to those people who best of all can control them. Stakeholders' desires concern all expected risks in the contract. It serves no useful purpose to force an onerous, one-sided contract on contractors and sub-contractors taking all the risk in the contract;

(f) Each project is unique. There is no same road to manage each project. Situations, people, and goals change over time. Never before has a project been available which has had the same circumstances and requirements. Situations, people, and purposes change over time. All new ideas and possible variants of decisions have to be compared by many criteria [30]. The complex nature of decision-making requires practitioners to select investment options by a broader palette of political reasons along with the analysis of a ratio of "expense effect" and purely technical reasons. In the economy and the development of the decision, it is essential that the impacts of cultural, social, moral, legislative, demographic, economic, ecological, state, and technological changes in the business world on the international, national, regional, and local markets are considered. The analysis of multi-criteria is a useful tool for many similar problems [31-33];

(g) The construction business is the industry, which slowly accepts innovations. The choice of more effective technological systems in the building is a complex task with several criteria [34];

(h) A client describes vaguely, continually changing requirements [35];

(i) Clients are slow with communication [36];

(j) Work is frequently seasonal;

(k) The construction process is not defined as predictable;

(l) Temporary restrictions. Time is money for the owner, building customer, and the user of the build facility. The delay in construction causes not only loss of profits, excesses of costs, and sometimes poor quality, but also many significant disputes, even full-time jobs, and many long-term challenges. A delay means the loss of the owner's income, such as production, and other commercial facilities are at disposal not in due in time. Baldwin and Manthei [37] described 17 delay factors: weather, labor resources, subcontractors, constructive changes, plans, fund status, material shortage, manufactured items, type approvals, jurisdictional disputes, denial of equipment, contracts, construction mistakes, inspections, finance, solutions, and construction standards and building regulations. Other factors contributing to the construction slowdown are labor-management relations, strikes, poor organization, planning, coordination, deteriorating quality of craft, productivity, lack of craftsmen skills, quality of training, delivery delays, and the high cost of financing. Additionally, Arditi et al. [38], among other things, observed the following reasons for delays in public projects in Turkey: lack of materials, difficulties in receiving payments from agencies, contractors' problems, and the specific characteristics of contractors and state institutions;

(m) Socio-political pressure. Political pressure and society affect public and private sector employees to some extent;

(n) The organization. The level of the structure should establish a formal system of human roles to achieve the goals of the company.

The project team has to solve all identified problems of the leadership in construction as soon as it is possible. Sexton and Senaratne [39] showed that the organization and design theories of management are in connection with problem-solving as an information-processing activity. Members of the project team brought various types of knowledge into the situation of a problem and created, captured, and shared it when solving a problem of management of project involving changes. 


\section{Model for Multi-Criteria Decision-Making in Construction Management}

\subsection{Multi-Criteria Methods and Construction Management}

Multi-criteria decision-making deals with making decisions where multiple criteria (usually being in contradiction) are present. Different criteria can have different specific qualitative features, units of measurement, and relative weight scales. There is the possibility that some of the criteria can only be described subjectively and others only measured numerically. Scientists developed the foundations of modern MCDM in the 1950s and 1960s. There are dozens of ways to solve MCDM problems. The MCDM methods grant the solutions for a whole series of management issues.

In the 1980s and at the beginning of 1990s, the development of MCDM methods grew rapidly. Koksalan et al. [40] and Kahraman et al. [41] gave a short history of the development of MCDM methods. Zavadskas and Turskis [42] and Zavadskas et al. [43] gave detailed studies about the application of the MCDM methods in different fields of the management and the economy. Jato-Espino et al. [44] reviewed applications of multi-criteria decision-making methods in construction. Mardani et al. [45] looked at the use of some multiple-criteria decision-making techniques. The most popular hybrid MCDM methods demonstrate the advantages over traditional ones to solve complicated problems which involve stakeholder preferences, interconnected or contradictory criteria, and uncertain environments. Decision-makers could use multi-criteria decision-making methods [46] such as analytic hierarchy process [47], fuzzy analytic hierarchy process [48,49], fuzzy Delphi [50], analytic network process under intuitionistic fuzzy set [51], Additive Ratio Assessment (ARAS) [52], simple additive weighting and game theory [53], discrete two persons' zero-sum matrix game theory [54], Evaluation based on Distance from Average Solution (EDAS), COPRAS, TOPSIS [55], as well as developing original models [56].

Saaty [57] published a detailed study on AHP applications. The extension of existing and integration of well-known methods or development of hybrid methods became common practice (primarily by the application of the fuzzy and grey systems theory). Some time ago COPRAS [58,59] and ARAS $[33,60]$ were presented by Lithuanian scientists. Later, MCDM methods such as multi-objective optimization on the basis of ratio analysis (MOORA) and MOORA plus full multiplicative form (MULTIMOORA) [61,62] were developed. Then, Step-Wise Weight Assessment Ratio Analysis (SWARA) [63], Weighted Aggregated Sum Product ASsessment (WASPAS) [64], and KEmeny Median Indicator Rank Accordance (KEMIRA) [65] appeared and were applied to particular real-life cases. Different modifications of the TOPSIS method is the second most widely used group of MCDM methods to solve complicated problems in construction [66]. Table 1 presents the most common problems solved using multi-criteria decision-making methods.

There are several possible consequences of which the owner who chooses a contractor who uses the method of low bidding should be informed of. First, one supposes by the process of the competitive auction that all enterprises (including the material suppliers, the general contractors, and the subcontractors) have submitted a proposal on the work that is as cheap as permitted, as the drawings and the technical specifications of the project have allowed. Secondly, there is the widespread mistake (particularly among the amateurs) that the technical requirements and the drawings will automatically mean that all contractors will provide the same results, and that the results will correspond to the expectations of the owner. Lastly, lacking any contractor input at this stage of project engineering, the total of the final low-bid is still unknown until the contractor actually finishes the project. This means that the architect and owner must wait uneasily until the design and bidding phases are completed before they will know if their plan is on, or under, or (more probably) over budget. 
Table 1. Most common problems solved by using multi-criteria decision-making methods (quantitative and qualitative $(\mathrm{Q} / \mathrm{Q})$, fuzzy $(\mathrm{F}))$.

\begin{tabular}{|c|c|c|c|}
\hline Considered Problem & $\begin{array}{l}\text { Information } \\
\text { Type }\end{array}$ & $\begin{array}{l}\text { Multiple Criteria } \\
\text { Method Used }\end{array}$ & Reference \\
\hline \multirow{2}{*}{ Construction project selection } & $\mathrm{Q} / \mathrm{Q}$ & COPRAS-G $^{1}$ & [59] \\
\hline & $\mathrm{F}$ & TOPSIS & [66] \\
\hline Choice of operating system & $\mathrm{F}$ & TOPSIS, AHP & [67] \\
\hline Service selection & $\mathrm{F}$ & $\begin{array}{c}\text { Grey correlation TOPSIS, } \\
\text { AHP }\end{array}$ & [68] \\
\hline $\begin{array}{l}\text { Selection of grippers, Selection } \\
\text { for financial investments, } \\
\text { Selecting robotic processes, } \\
\text { Comparing company } \\
\text { performances, Comparing } \\
\text { financial ratio performance }\end{array}$ & $\mathrm{F}$ & TOPSIS & [69] \\
\hline $\begin{array}{l}\text { Wastewater treatment process } \\
\text { selection }\end{array}$ & $\mathrm{F}$ & TOPSIS, AHP & {$[70]$} \\
\hline $\begin{array}{c}\text { Selection of sustainable } \\
\text { investment }\end{array}$ & $\mathrm{F}$ & TOPSIS & [71] \\
\hline $\begin{array}{c}\text { Green building material } \\
\text { selection }\end{array}$ & $\mathrm{F}$ & $\mathrm{ANP}^{2}$, DEMATEL & [72] \\
\hline $\begin{array}{l}\text { Determination of strategic } \\
\text { priorities by analysis of } \\
\text { strengths, weaknesses, } \\
\text { opportunities and threats } \\
\text { (SWOT) }\end{array}$ & $\mathrm{F}$ & Goal Programming & [73] \\
\hline $\begin{array}{l}\text { Project management critical } \\
\text { success factors }\end{array}$ & $\mathrm{F}$ & ANP, DEMATEL & [74] \\
\hline $\begin{array}{l}\text { Material selection and new } \\
\text { product development }\end{array}$ & $\mathrm{F}$ & COPRAS & [75] \\
\hline $\begin{array}{l}\text { Choice of the action plan and } \\
\text { dynamic supplier selection }\end{array}$ & $\mathrm{F}$ & $\begin{array}{l}\text { Mixed integer linear } \\
\text { programming }\end{array}$ & [76] \\
\hline $\begin{array}{c}\text { Sustainable building } \\
\text { assessment/certification }\end{array}$ & $\mathrm{Q} / \mathrm{Q}$ & ARAS & [77] \\
\hline $\begin{array}{l}\text { Selection of suitable bridge } \\
\text { construction method }\end{array}$ & $\mathrm{F}$ & $\mathrm{AHP}$ & [78] \\
\hline Selection of construction site & $\mathrm{F}$ & ARAS and AHP & [79] \\
\hline Design of products & $\mathrm{Q} / \mathrm{Q}$ & $\begin{array}{l}\text { Yin-Yang balance, } \\
\text { SWARA }\end{array}$ & [80] \\
\hline \multirow{2}{*}{ Supplier selection } & $\mathrm{F}$ & TOPSIS & [81] \\
\hline & $\mathrm{F}$ & TOPSIS, AHP & [82] \\
\hline \multirow{6}{*}{ Contractor selection } & $\mathrm{F}$ & AHP, PERT $^{3}$ & [83] \\
\hline & $\mathrm{Q} / \mathrm{Q}$ & $\mathrm{QBS}^{4}$ & [84] \\
\hline & $\mathrm{Q} / \mathrm{Q}$ & QBS, Low Bid & [85] \\
\hline & $\mathrm{F}$ & $\mathrm{MFPR}^{5}$ & {$[86]$} \\
\hline & $\mathrm{F}$ & TOPSIS, AHP & [87] \\
\hline & $\mathrm{Q} / \mathrm{Q}$ & Best-Value, AHP & [88] \\
\hline
\end{tabular}

${ }_{1}$ COmplex PRoportional ASsessment of alternatives with grey relations (COPRAS-G); ${ }^{2}$ Analytic Network Process (ANP); ${ }^{3}$ Program Evaluation and Review Technique (PERT); ${ }^{4}$ Qualifications Based Selection (QBS); ${ }^{5}$ Multiple-layer Fuzzy Pattern Recognition. 


\subsection{Model Development for Multi-Criteria Decision-making}

The specific steps are essential to solve a multi-criteria decision-making problem. Figure 3 presents the developed approach. First, decision-makers define all feasible alternatives to the problem solution. Second, they should set the alternatives' criteria. Decision-makers identify factors, which have an essential influence on and are important to the contractor's choices. Third, the stakeholder identifies goals and a set of criteria. Fourth, decision-makers define the values of criteria, because each criterion has its value for a different specific choice. As an example, an experience of each contractor given as outstanding (OT) or right, average (AV) or below average (BA), and lastly as unsatisfactory (UN). On the other hand, profitability defined as either high (HG), average (AV) or even low (LW), and others. Fourth, it is necessary to establish criteria weights where one can identify more or less essential criteria. The more critical criteria are given greater weight. Then, decision-makers evaluate alternatives. Lastly, the best option is chosen using calculations aided by computer software.

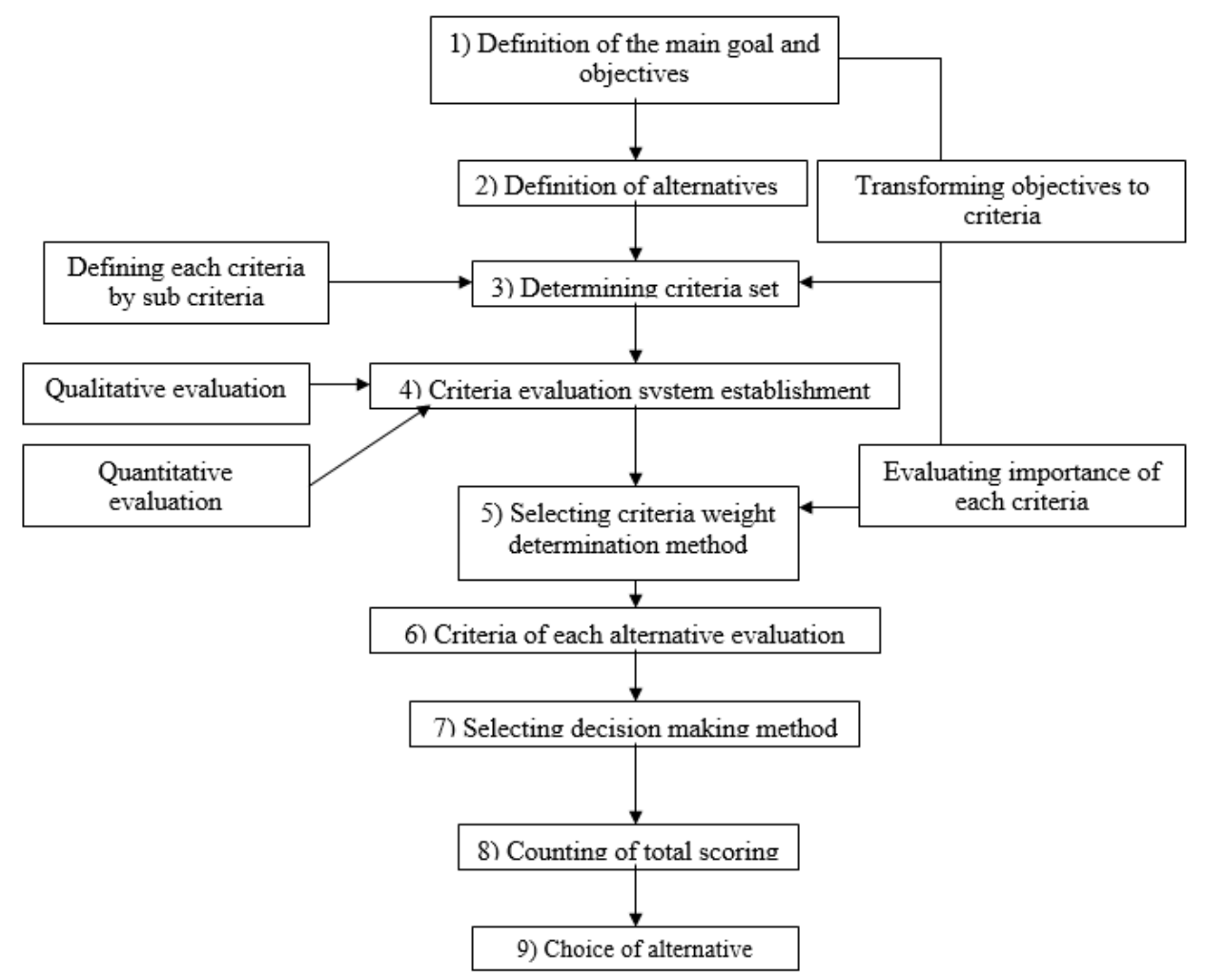

Figure 3. Framework for decision-making in a construction model.

\section{Case Study: Turkish Construction Project Management-Sustainable Decision-Making: Finding the Best Contractor}

\subsection{Project Description and Problem Considered}

In construction, one of the most critical tasks is selecting the right contractor. It is a multi-criteria problem including both quantitative and qualitative factors. To choose the right contractor from many applicants available in today's market is a somewhat complicated problem for clients. Selecting of a proper contractor is crucially important to ensure the quality of the constructed building when dealing with long-term assets. To achieve this aim, it will largely depend on the efficiency of the performance of the selected contractor [89]. Studies of contractor selection date back to the early 1960s.

A three-star seven-story hotel is to be built in the south of Turkey, close to Antalya. The hotel stakeholders want to create a swimming pool. The measurements are:

- Oval shape; 
- 25-m long;

- $\quad 10-\mathrm{m}$ wide;

- 2.2-m deep.

A little amount of work is left to finish the project. The project manager has to select a building contractor. The primary objective is to choose the correct contractor for the pool. Picking the right contractor to build the pool is the primary aim. The main criteria are:

- Good design;

- Good quality;

- Best financial options.

\subsection{Making Alternatives}

This example shows the selection of the contractor based on analysis using multi-criteria methodologies. The contractor choice is a significant decision for a construction manager, as the success of the whole project will be affected.

Stakeholders will select the contractor from five contractors. The selection of the contractor is based on the use of multi-criteria methods to evaluate and combine objective and subjective criteria with a significant impact on the effective implementation of the construction project. All contractors are well-known companies in Turkey from Ankara, Istanbul, and Izmir.

\subsection{Setting the Criteria, Determining Their Values}

Contractor choice for the project will be dependent on many different things. Some are more important, for example, technical experience. Others, such as their safety record are not so important.

Thus, when choosing, it is essential to evaluate a contractor's:

(1) technical experience,

(2) record of performance,

(3) financial stability,

(4) the qualifications of the employees and the management,

(5) capacity,

(6) safety record, and

(7) equipment and operation.

These main criteria should be taken into account while choosing, but also secondary criteria must be evaluated, for example, capacity, the number of projects on which the contractor is currently working, etc. The criteria set was determined by questioning experts and stakeholders and based on the literature overview. Figure 4 presents the criteria and sub-criteria sets, which influence the choice of the contractor in this project. 


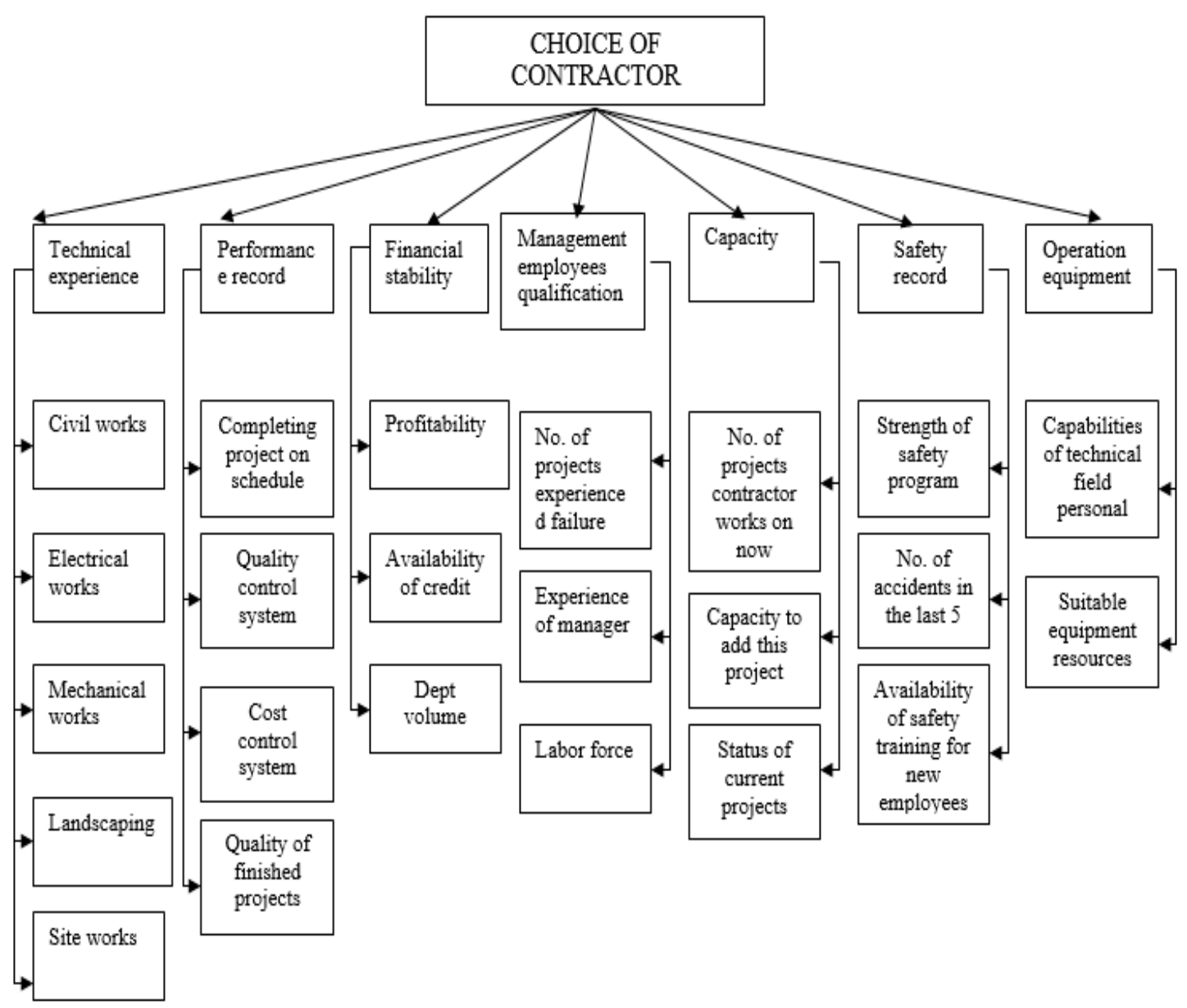

Figure 4. Set of criteria system.

It means that this model has two levels; main criteria and secondary criteria.

- Technical Experience (TE)—-this shows the contractor's experience in civil (TE1), electrical (TE2), mechanical (TE3), landscaping (TE4), and site (TE5) works. The project number is considered as an essential criterion. If the contractor has completed $>20$ projects, the evaluation can be considered as outstanding (OT), 15-10 very good (VG), 10-15 average (AV), 5-10 below average (BA), and fewer than five projects - unsatisfactory (UN).

- Performance Record (PE)—shows if the contractor usually completes projects on time (PE1) (always (AL), sometimes (SM), or rarely (RR), and will evaluate any quality (PE2) and cost control (PE3) systems, including the finished project quality (PE4). PE2, PE3 and PE4 are assessed as either outstanding (OT) or very good (VG), average (AV) or below average (BA), or unsatisfactory (UN).

- Financial Stability (FS) — evaluates such things as the contractor's profitability (FS1), credit availability (FS2), as well as debt (FS3). Either high (HG), average (AV) or low (LW).

- Qualification of Management Employees (ME) - This evaluates the number of failures in the contractor's projects (ME1) (never $(0), 3$ or less $(\leq 3)$, more than $3(>3)$, experience of managers (ME2) (less than 5 years $(<5)$, from 5 to 10 years $(5-10)$, more than 10 year $(>10)$ and workers' experience (ME3) (strong (S), moderate $(\mathrm{M})$, poor $(\mathrm{P})$.

- Capacity (CA) - This will evaluate the projects the contractor is working on (CA1) (less than 5 $(<5)$, from 5 to $10(5-10)$, more than $10(>10)$, and the ability (capacity) to include this project (CA2) strong (S), moderate (M), and weak (W), as well as ongoing project status (CA3). Evaluation of status of current (ongoing) projects: ahead of schedule (SA), as scheduled (SO), behind schedule (SB), and stopped (SS). 
- Safety Record (SR) - This is about the strengths of the safety program (SR1) (outstanding (OT) or very good (VG), average (AV) or below average (BA), or unsatisfactory (UN), number of accidents that happened in the last five years (SR2) (less than $5(<5)$, from 5 to $10(5-10)$, more than $10(>10)$, and availability of safety training for new employees (SR3) (available (Yes), not available (No).

- Operation and Equipment (OE) - This shows the expertise of technical field employees (OE1) (outstanding (OT) or very good (VG), average (AV) or below average (BA), or unsatisfactory (UN) and equipment suitability (OE2). The secondary criteria, (e.g., technical field personnel abilities), are evaluated qualitatively, depending on the competencies of employees: very suitable (VS), average $(\mathrm{AV})$, acceptable $(\mathrm{AC})$, unsatisfactory $(\mathrm{UN})$.

Criteria are worked out depending on their origin. Table 2 provides a possible evaluation of criteria and sub-criteria. As it shows, aspects of technical experience can be evaluated on a scale from OT to UN, etc. It means that this model has two levels; main criteria and secondary criteria.

Table 2. Evaluation of criteria.

\begin{tabular}{|c|c|c|c|c|c|c|}
\hline Criteria & Sub-Criteria & & & Evalua & & \\
\hline \multirow{5}{*}{$\mathrm{TE}$} & TE1 & OT & VG & $\mathrm{AV}$ & $\mathrm{BA}$ & UN \\
\hline & TE2 & OT & VG & $\mathrm{AV}$ & $\mathrm{BA}$ & UN \\
\hline & TE3 & OT & VG & $\mathrm{AV}$ & $\mathrm{BA}$ & UN \\
\hline & TE4 & OT & VG & $\mathrm{AV}$ & BA & UN \\
\hline & TE5 & OT & VG & $\mathrm{AV}$ & BA & UN \\
\hline \multirow{4}{*}{ PE } & PE1 & $\mathrm{AL}$ & $\mathrm{SM}$ & $\mathrm{RR}$ & - & - \\
\hline & PE2 & OT & VG & $\mathrm{AV}$ & BA & UN \\
\hline & PE3 & OT & VG & $\mathrm{AV}$ & BA & UN \\
\hline & PE4 & OT & VG & $\mathrm{AV}$ & BA & UN \\
\hline \multirow{3}{*}{ FS } & FS1 & HG & $\mathrm{AV}$ & LW & - & - \\
\hline & FS2 & HG & $\mathrm{AV}$ & LW & - & - \\
\hline & FS3 & HG & AV & LW & - & - \\
\hline \multirow{3}{*}{ ME } & ME1 & 0 & $\leq 3$ & $>3$ & - & - \\
\hline & ME2 & $<5$ & $5-10$ & $>10$ & - & - \\
\hline & ME3 & $S$ & M & $\mathrm{P}$ & - & - \\
\hline \multirow{3}{*}{ CA } & CA1 & $<5$ & $5-10$ & $>10$ & - & - \\
\hline & CA2 & $S$ & M & $\mathrm{W}$ & - & - \\
\hline & CA3 & SA & $\mathrm{SO}$ & SB & SS & - \\
\hline \multirow{3}{*}{ SR } & SR1 & OT & VG & $\mathrm{AV}$ & $\mathrm{BA}$ & UN \\
\hline & SR2 & $<5$ & $5-10$ & $>10$ & - & - \\
\hline & SR3 & Yes & No & - & - & - \\
\hline \multirow{2}{*}{$\mathrm{OE}$} & OE1 & OT & VG & AV & $\mathrm{BA}$ & UN \\
\hline & OE2 & VS & $\mathrm{AV}$ & $\mathrm{AC}$ & UN & - \\
\hline
\end{tabular}

\subsection{Calculation According to the Model}

The criteria were weighted using "Expert Choice" software (based on the AHP method). From the model, factors (criteria) of level one (Figure 4) were as input, which was calculated using the software. Firstly, the main criteria's weights were worked out. The team of experts discussed the initial matrix for comparing the relative importance of the criteria in pairs. Table 3 provides a comparison matrix. 
Table 3. Comparison matrix.

\begin{tabular}{ccccccccc}
\hline Criteria & TE & PE & FS & ME & CA & SR & OE & $\begin{array}{c}\text { Criteria } \\
\text { Weights }\end{array}$ \\
\hline TE & 1 & 2 & 5 & 5 & 6 & 6 & 2 & 0.33 \\
\hline PE & - & 1 & 6 & 6 & 7 & 6 & 2 & 0.29 \\
\hline FS & - & - & 1 & 1 & 3 & 3 & 1 & 0.09 \\
\hline ME & - & - & - & 1 & 4 & 3 & $1 / 3$ & 0.08 \\
\hline CA & - & - & - & - & 1 & 2 & $1 / 5$ & 0.04 \\
\hline SR & - & - & - & - & - & 1 & $1 / 4$ & 0.03 \\
\hline OE & - & - & - & - & - & - & 1 & 0.15 \\
\hline & & \multicolumn{7}{c}{$\mathbf{C R}=0.05$} \\
\hline
\end{tabular}

If $\mathrm{CR}$ is less than 0.1, then it is assumed that the expert is consistent in his evaluations.

In a similar way, the weights of the sub-criteria were determined for each of the criteria groups. Table 4 presents the summary of the defined criteria and sub-criteria weights.

Table 4. Weights of the criteria and sub-criteria.

\begin{tabular}{|c|c|c|c|}
\hline Criteria & Weight & Sub-Criteria & Weight \\
\hline \multirow{5}{*}{$\mathrm{TE}$} & \multirow{5}{*}{0.33} & TE1 & 0.19 \\
\hline & & TE2 & 0.02 \\
\hline & & TE3 & 0.07 \\
\hline & & TE4 & 0.02 \\
\hline & & TE5 & 0.03 \\
\hline \multirow{4}{*}{$\mathrm{PE}$} & \multirow{4}{*}{0.29} & PE1 & 0.07 \\
\hline & & PE2 & 0.07 \\
\hline & & PE3 & 0.07 \\
\hline & & PE4 & 0.07 \\
\hline \multirow{3}{*}{ FS } & \multirow{3}{*}{0.09} & FS1 & 0.02 \\
\hline & & FS2 & 0.05 \\
\hline & & FS3 & 0.02 \\
\hline \multirow{3}{*}{$\mathrm{ME}$} & \multirow{3}{*}{0.08} & ME1 & 0.06 \\
\hline & & ME2 & 0.01 \\
\hline & & ME3 & 0.01 \\
\hline \multirow{3}{*}{ CA } & \multirow{3}{*}{0.04} & CA1 & 0.01 \\
\hline & & CA2 & 0.01 \\
\hline & & CA3 & 0.02 \\
\hline \multirow{3}{*}{ SR } & \multirow{3}{*}{0.03} & SR1 & 0.01 \\
\hline & & SR2 & 0.02 \\
\hline & & SR3 & 0.00 \\
\hline \multirow{2}{*}{$\mathrm{OE}$} & \multirow{2}{*}{0.15} & OE1 & 0.15 \\
\hline & & OE2 & 0.00 \\
\hline
\end{tabular}


Therefore, criteria rank according to importance are as follows: TE (the most important); PE; OE; FS; ME; CA; SR (the least important).

Table 5 provides information on the evaluation of each criterion and sub-criterion for each of the five contractors. Criteria evaluated according to their PE and other information.

Table 5. Evaluation of contractors based on the criteria set.

\begin{tabular}{|c|c|c|c|c|c|c|}
\hline \multirow{2}{*}{ Criteria } & \multirow{2}{*}{ Sub-Criteria } & \multicolumn{5}{|c|}{ Contractor } \\
\hline & & $\mathrm{C}_{1}$ & $\mathrm{C}_{2}$ & $\mathrm{C}_{3}$ & $\mathrm{C}_{4}$ & $\mathrm{C}_{5}$ \\
\hline \multirow{5}{*}{$\mathrm{TE}$} & TE1 & VG & VG & OT & AV & $\mathrm{AV}$ \\
\hline & TE2 & VG & VG & OT & BA & $\mathrm{AV}$ \\
\hline & TE3 & VG & VG & OT & BA & $\mathrm{AV}$ \\
\hline & TE4 & VG & VG & OT & BA & $\mathrm{AV}$ \\
\hline & TE5 & VG & VG & OT & AV & $\mathrm{AV}$ \\
\hline \multirow{4}{*}{ PE } & PE1 & SM & $\mathrm{SM}$ & $\mathrm{AL}$ & $\mathrm{RR}$ & SM \\
\hline & PE2 & VG & AV & VG & UN & $\mathrm{AV}$ \\
\hline & PE3 & AV & AV & VG & UN & BA \\
\hline & PE4 & VG & VG & OT & $\mathrm{BA}$ & $\mathrm{AV}$ \\
\hline \multirow{3}{*}{ FS } & FS1 & AV & HG & $\mathrm{HG}$ & LW & $\mathrm{AV}$ \\
\hline & FS2 & $\mathrm{AV}$ & HG & $\mathrm{AV}$ & LW & LW \\
\hline & FS3 & LW & LW & LW & LW & $\mathrm{AV}$ \\
\hline \multirow{3}{*}{$\mathrm{ME}$} & ME1 & $\leq 3$ & 0 & 0 & $>3$ & 0 \\
\hline & ME2 & $>10$ & $5-10$ & $>10$ & $<5$ & $5-10$ \\
\hline & ME3 & M & M & M & $\mathrm{P}$ & M \\
\hline \multirow{3}{*}{ CA } & CA1 & $<5$ & $5-10$ & $>10$ & $<5$ & $>10$ \\
\hline & CA2 & S & M & W & S & W \\
\hline & CA3 & SB & SO & $\mathrm{SO}$ & SB & SB \\
\hline \multirow{3}{*}{ SR } & SR1 & BA & BA & AV & UN & UN \\
\hline & SR2 & $<5$ & $<5$ & $>10$ & 5-10 & $>10$ \\
\hline & SR3 & No & No & Yes & No & No \\
\hline \multirow{2}{*}{$\mathrm{OE}$} & OE1 & AV & AV & VG & BA & BA \\
\hline & OE2 & AV & AV & VS & UN & $\mathrm{AC}$ \\
\hline
\end{tabular}

Decision-makers prepared the initial decision-making matrix for problem-solving based on Saaty's [45] scale.

Finally, Table 6 provides the overall scoring of each contractor on different criteria. The "Expert Choice" program scored different criteria values of each contractor.

In Table 6, all optional values are the biggest values:

$$
K_{j}=\sum_{i=1}^{m} \frac{x_{i j} w_{i}}{\sum_{j=1}^{n} x_{i j}}
$$

where: $w_{i}$-weight of sub-criteria; $x_{i j}$ - evaluation of $i$ contractor according to the $j$ criterion; $I=1, m$; $j=1, n$; $m$-number of criteria; $n$-number of contractors.

According to Table 6, the best contractor is $C_{3}$ because their score is 0.55 , the worst contractor is contractor $\mathrm{C}_{4}$ because their score is 0.15 . 
Table 6. Overall scoring of contractors.

\begin{tabular}{|c|c|c|c|c|c|c|}
\hline \multirow{2}{*}{ Criteria } & \multirow{2}{*}{ Sub-Criteria } & \multicolumn{5}{|c|}{ Contractor } \\
\hline & & $\mathrm{C}_{1}$ & $\mathrm{C}_{2}$ & $\mathrm{C}_{3}$ & $\mathrm{C}_{4}$ & $\mathrm{C}_{5}$ \\
\hline \multirow{5}{*}{$\mathrm{TE}$} & TE1 & 0.10 & 0.10 & 0.02 & 0.05 & 0.05 \\
\hline & TE2 & 0.01 & 0.01 & 0.02 & 0.00 & 0.00 \\
\hline & TE3 & 0.04 & 0.04 & 0.03 & 0.01 & 0.02 \\
\hline & TE4 & 0.01 & 0.01 & 0.02 & 0.00 & 0.00 \\
\hline & TE5 & 0.02 & 0.02 & 0.03 & 0.01 & 0.01 \\
\hline \multirow{4}{*}{ PE } & PE1 & 0.02 & 0.02 & 0.07 & 0.01 & 0.02 \\
\hline & PE2 & 0.04 & 0.02 & 0.04 & 0.01 & 0.02 \\
\hline & PE3 & 0.02 & 0.02 & 0.04 & 0.01 & 0.01 \\
\hline & PE4 & 0.04 & 0.04 & 0.07 & 0.01 & 0.02 \\
\hline \multirow{3}{*}{ FS } & FS1 & 0.00 & 0.02 & 0.02 & 0.00 & 0.00 \\
\hline & FS2 & 0.01 & 0.05 & 0.01 & 0.01 & 0.01 \\
\hline & FS3 & 0.00 & 0.00 & 0.00 & 0.00 & 0.00 \\
\hline \multirow{3}{*}{ ME } & ME1 & 0.01 & 0.06 & 0.06 & 0.01 & 0.06 \\
\hline & ME2 & 0.01 & 0.00 & 0.01 & 0.00 & 0.00 \\
\hline & ME3 & 0.00 & 0.00 & 0.00 & 0.00 & 0.00 \\
\hline \multirow{3}{*}{ CA } & CA1 & 0.01 & 0.00 & 0.00 & 0.01 & 0.00 \\
\hline & CA2 & 0.01 & 0.00 & 0.00 & 0.01 & 0.00 \\
\hline & CA3 & 0.01 & 0.01 & 0.01 & 0.01 & 0.01 \\
\hline \multirow{3}{*}{ SR } & SR1 & 0.00 & 0.00 & 0.00 & 0.00 & 0.00 \\
\hline & SR2 & 0.02 & 0.02 & 0.00 & 0.01 & 0.00 \\
\hline & SR3 & 0.00 & 0.00 & 0.00 & 0.00 & 0.00 \\
\hline \multirow{3}{*}{$\mathrm{OE}$} & OE1 & 0.02 & 0.02 & 0.05 & 0.01 & 0.01 \\
\hline & OE2 & 0.02 & 0.02 & 0.05 & 0.00 & 0.01 \\
\hline & $\Sigma$ & 0.40 & 0.47 & 0.55 & 0.15 & 0.25 \\
\hline
\end{tabular}

\section{Conclusions}

A large number of problems in construction management are those of MCDM. To counter the complex nature of a problem, one can use four optimization methods. These are multi-criteria, cost-oriented, single-objective, and multi-objective. The case study identified ten groups of significant construction management problems. One of the most important is choosing the right contractor.

Project managers could use optimization, elimination, and probabilistic methods to select and background effective decisions. The multiple-criteria side is significant when decisions deal with construction management.

The research suggested the nine-stage model for decision-making problem-solving. The stages are as follows: (a) definition of the primary goal and objectives; (b) definition of alternatives; (c) determining the criteria set; (d) establishment of a criteria evaluation system; (e) selecting the criteria weight determination method; (f) determining criteria values for each alternative under consideration; (g) selecting a decision-making method; (h) counting of the total performance score; (j) choice of an option to implement.

Based on the overview of the literature, and expert judgement criteria set was worked out as follows: (a) performance; (b) technical experience; (c) stability of finances; (d) management performance/employee qualification; (e) capacity; (f) record of safety; (g) equipment operation. 
The model proposed was used to select a sustainable contractor in the construction of the pool at the seven-story hotel near the Mediterranean Sea in Turkey. After analyzing the alternatives, the best contractor was $\mathrm{C}_{3}$ (with a total score of 0.55 ).

Author Contributions: Conceptualization, S.A.E. and J.Š.; Methodology, S.A.E. and Z.T.; Formal Analysis, S.A.E. and Z.T.; Investigation, S.A.E.; Data Curation, S.A.E.; Writing—Original Draft Preparation, J.Š.; Writing-Review and Editing, S.A.E. and J.Š.; Visualization, S.A.E.; Supervision, Z.T.

Funding: This research received no external funding.

Conflicts of Interest: The authors declare no conflict of interest.

\section{References}

1. Yu, M.; Zhu, F.; Yang, X.; Wang, L.; Sun, X. Integrating Sustainability into Construction Engineering Projects: Perspective of Sustainable Project Planning. Sustainability 2018, 10, 784. [CrossRef]

2. Aziz, R.F.; Hafez, S.M. Applying lean thinking in construction and performance improvement. Alex. Eng. J. 2013, 52, 679-695. [CrossRef]

3. Whyte, J.; Stasis, A.; Lindkvist, C. Managing change in the delivery of complex projects: Configuration management, asset information and 'big data'. Int. J. Proj. Manag. 2015, 34, 339-351. [CrossRef]

4. Hoda, R.; Murugesan, L.K. Multi-level agile project management challenges: A self-organizing team perspective. J. Syst. Softw. 2016, 117, 245-257. [CrossRef]

5. Sarma, S.P. Professional Management; New Age International Pvt Ltd.: Calcuta, India, 1998.

6. Confucius. The Doctrine of the Mean; Translated by James Legge; The University of Adelaide: Adelaide, Australia, 2014.

7. Schoemaker, P.J.H.; Russo, J.E. A pyramid of decision approaches. Calif. Manag. Rev. 1993, 36, 9-31. [CrossRef]

8. Carter, C.F.; Williams, B.R. Industry and Technical Progress: Factors Governing the Speed of Application of Science; Oxford University Press: London, UK, 1957.

9. Levitt, T. Marketing Myopia. Harv. Bus. Rev. 1960, 38, 45-56. [CrossRef]

10. Dickson, G.W. An analysis of vendor selection systems and decisions. J. Purch. 1966, 2, 5-17. [CrossRef]

11. Strauss, G. Tactics of lateral relationships. Adm. Sci. Q. 1962, 7, 161-186. [CrossRef]

12. Pretzsch, J. Paradigms of tropical forestry in rural development. In Forests and Rural Development; Springer: Berlin/Heidelberg, Germany, 2014; pp. 7-49.

13. Yazdani, M.; Chatterjee, P.; Zavadskas, E.K.; Zolfani, S.H. Integrated QFD-MCDM framework for green supplier selection. J. Clean. Prod. 2017, 142, 3728-3740. [CrossRef]

14. Kamali, M.; Hewage, K. Development of performance criteria for sustainability evaluation of modular versus conventional construction methods. J. Clean. Prod. 2017, 142, 3592-3606. [CrossRef]

15. Heravi, G.; Fathi, M.; Faeghi, S. Multi-criteria group decision-making method for optimal selection of sustainable industrial building options focused on petrochemical projects. J. Clean. Prod. 2017, 142, 2999-3013. [CrossRef]

16. Rashid, K.; Razzaq, A.; Ahmad, M.; Rashid, T.; Tariq, S. Experimental and analytical selection of sustainable recycled concrete with ceramic waste aggregate. Constr. Build. Mater. 2017, 154, 829-840. [CrossRef]

17. Diaz-Sarachaga, J.M.; Jato-Espino, D.; Castro-Fresno, D. Methodology for the development of a new Sustainable Infrastructure Rating System for Developing Countries (SIRSDEC). Environ. Sci. Policy 2017, 69, 65-72. [CrossRef]

18. Bansal, S.; Biswas, S.; Singh, S.K. Fuzzy decision approach for selection of most suitable construction method of Green Buildings. Int. J. Sustain. Built Environ. 2017, 6, 122-132. [CrossRef]

19. Vassoney, E.; Mochet, A.M.; Comoglio, C. Use of multicriteria analysis (MCA) for sustainable hydropower planning and management. J. Environ. Manag. 2017, 196, 48-55. [CrossRef] [PubMed]

20. Islam, M.S.; Nepal, M.P.; Skitmore, M.; Attarzadeh, M. Current research trends and application areas of fuzzy and hybrid methods to the risk assessment of construction projects. Adv. Eng. Inform. 2017, 33, 112-131. [CrossRef]

21. Diaz-Balteiro, L.; González-Pachón, J.; Romero, C. Measuring systems sustainability with multi-criteria methods: A critical review. Eur. J. Oper. Res. 2017, 258, 607-616. [CrossRef] 
22. Myers, J.H.; Alpert, M.I. Determinant buying attitudes: Meaning and measurement. J. Mark. 1968, 32, 13-20. [CrossRef]

23. Luthra, S.; Govindan, K.; Kannan, D.; Mangla, S.K.; Garg, C.P. An integrated framework for sustainable supplier selection and evaluation in supply chains. J. Clean. Prod. 2017, 140, 1686-1698. [CrossRef]

24. Junior, F.R.L.; Osiro, L.; Carpinetti, L.C.R. A comparison between Fuzzy AHP and Fuzzy TOPSIS methods to supplier selection. Appl. Soft Comput. 2014, 21, 194-209. [CrossRef]

25. Wu, J. A SD-IITFOWA operator and TOPSIS based approach for MAGDM problems with intuitionistic trapezoidal fuzzy numbers. Technol. Econ. Dev. Econ. 2015, 21, 28-47. [CrossRef]

26. Zavadskas, E.K.; Vilutienè, T.; Turskis, Z.; Tamošaitienè, J. Contractor selection for construction works by applying SAW-G and TOPSIS grey techniques. J. Bus. Econ. Manag. 2010, 11, 34-55. [CrossRef]

27. Makovšek, D. Systematic construction risk, cost estimation mechanism and unit price movements. Transp. Policy 2014, 35, 135-145. [CrossRef]

28. Fouladgar, M.M.; Yazdani-Chamzini, A.; Lashgari, A.; Zavadskas, E.K.; Turskis, Z. Maintenance strategy selection using AHP and COPRAS under fuzzy environment. Int. J. Strateg. Prop. Manag. 2012, 16, 85-104. [CrossRef]

29. Peldschus, F.; Zavadskas, E.K.; Turskis, Z.; Tamošaitienè, J. Sustainable assessment of construction site by applying game theory. Inz. Ekon.-Eng. Econ. 2010, 21, 223-237.

30. Turskis, Z.; Zavadskas, E.K.; Peldschus, F. Multi-criteria optimization system for decision making in construction design and management. Inz. Ekon.-Eng. Econ. 2009, 61, 7-17.

31. Zagorskas, J.; Zavadskas, E.K.; Turskis, Z.; Burinskienè, M.; Blumberga, A.; Blumberga, D. Thermal insulation alternatives of historic brick buildings in Baltic Sea Region. Energy Build. 2014, 78, 35-42. [CrossRef]

32. Brauers, W.K.M.; Zavadskas, E.K.; Peldschus, F.; Turskis, Z. Multi-objective decision-making for road design. Transport 2008, 23, 183-193. [CrossRef]

33. Zavadskas, E.K.; Turskis, Z. A new additive ratio assessment (ARAS) method in multicriteria decision-making. Technol. Econ. Dev. Econ. 2010, 16, 159-172. [CrossRef]

34. Zavadskas, E.K.; Turskis, Z.; Volvačiovas, R.; Kildienè, S. Multi-criteria assessment model of technologies. Stud. Inform. Control 2013, 22, 249-258. [CrossRef]

35. Sivilevičius, H.; Zavadskas, E.K.; Turskis, Z. Quality attributes and complex assessment methodology of the asphalt mixing plant. Balt. J. Road Bridge Eng. 2008, 3, 161-166. [CrossRef]

36. Zavadskas, E.K.; Kaklauskas, A.; Turskis, Z.; Kalibatas, D. An approach to multi-attribute assessment of indoor environment before and after refurbishment of dwellings. J. Environ. Eng. Landsc. Manag. 2009, 17, 5-11. [CrossRef]

37. Baldwin, J.R.; Manthei, J.M. Causes of delays in the construction industry. ASCE J. Constr. Div. 1971, 97, 177-187.

38. Arditi, R.D.; Akan, G.T.; Gurdamar, S. Reasons for delays in public projects in Turkey. Constr. Manag. Econ. 1985, 3, 171-181. [CrossRef]

39. Senaratne, S.; Sexton, M. Managing construction project change: A knowledge management perspective. Constr. Manag. Econ. 2008, 26, 1303-1311. [CrossRef]

40. Köksalan, M.M.; Wallenius, J.; Zionts, S. Multiple Criteria Decision Making: From Early History to the 21st Century; World Scientific: Singapore, 2011.

41. Kahraman, C.; Onar, S.C.; Oztaysi, B. Fuzzy multicriteria decision-making: A literature review. Int. J. Comput. Intell. Syst. 2015, 8, 637-666. [CrossRef]

42. Zavadskas, E.K.; Turskis, Z. Multiple criteria decision making (MCDM) methods in economics: An overview. Technol. Econ. Dev. Econ. 2011, 17,397-427. [CrossRef]

43. Zavadskas, E.K.; Turskis, Z.; Kildienè, S. State of art surveys of overviews on MCDM/MADM methods. Technol. Econ. Dev. Econ. 2014, 20, 165-179. [CrossRef]

44. Jato-Espino, D.; Castillo-Lopez, E.; Rodriguez-Hernandez, J.; Canteras-Jordana, J.C. A review of application of multi-criteria decision making methods in construction. Autom. Constr. 2014, 45, 151-162. [CrossRef]

45. Mardani, A.; Jusoh, A.; Nor, K.M.D.; Khalifah, Z.; Zakwan, N.; Valipour, A. Multiple criteria decision-making techniques and their applications-A review of the literature from 2000 to 2014. Econ. Res.-Ekon. Istraz. 2015, 28, 516-571. [CrossRef]

46. Ye, K.; Zeng, D.; Wong, J. Competition rule of the multi-criteria approach: What contractors in China really want? J. Civ. Eng. Manag. 2018, 24, 155-166. [CrossRef] 
47. De la Fuente, A.; Armengou, J.; Pons, O.; Aguado, A. Multi-criteria decision-making model for assessing the sustainability index of wind-turbine support systems: Application to a new precast concrete alternative. J. Civ. Eng. Manag. 2017, 23, 194-203. [CrossRef]

48. Leśniak, A.; Kubek, D.; Plebankiewicz, E.; Zima, K.; Belniak, S. Fuzzy AHP application for supporting contractors' bidding decision. Symmetry 2018, 10, 642. [CrossRef]

49. Prascevic, N.; Prascevic, Z. Application of fuzzy AHP for ranking and selection of alternatives in construction project management. J. Civ. Eng. Manag. 2017, 23, 1123-1135. [CrossRef]

50. Chen, C.J.; Juan, Y.K.; Hsu, Y.H. Developing a systematic approach to evaluate and predict building service life. J. Civ. Eng. Manag. 2017, 23, 890-901. [CrossRef]

51. Štreimikienè, D.; Šliogerienè, J.; Turskis, Z. Multi-criteria analysis of electricity generation technologies in Lithuania. Renew. Energy 2016, 85, 148-156. [CrossRef]

52. Shariati, S.; Abedi, M.; Saedi, A.; Yazdani-Chamzini, A.; Tamošaitienè, J.; Šaparauskas, J.; Stupak, S. Critical factors of the application of nanotechnology in construction industry by using ANP technique under fuzzy intuitionistic environment. J. Civ. Eng. Manag. 2017, 23, 914-925. [CrossRef]

53. Kalibatas, D.; Kovaitis, V. Selecting the most effective alternative of waterproofing membranes for multifunctional inverted flat roofs. J. Civ. Eng. Manag. 2017, 23, 650-660. [CrossRef]

54. Gardziejczyk, W.; Zabicki, P. Normalization and variant assessment methods in selection of road alignment variants-case study. J. Civ. Eng. Manag. 2017, 23, 510-523. [CrossRef]

55. Bielinskas, V.; Burinskienè, M.; Podviezko, A. Choice of abandoned territories conversion scenario according to MCDA methods. J. Civ. Eng. Manag. 2018, 24, 79-92. [CrossRef]

56. Keshavarz Ghorabaee, M.; Zavadskas, E.K.; Olfat, L.; Turskis, Z. Multi-criteria inventory classification using a new method of evaluation based on distance from average solution (EDAS). Informatica 2015, 26, 435-451. [CrossRef]

57. Saaty, T.L. The Analytic Hierarchy Process: Planning, Priority Setting, Resources Allocation; McGraw-Hill: New York, NY, USA, 1980.

58. Zavadskas, E.K.; Kaklauskas, A. Determination of an efficient contractor by using the new method of multicriteria assessment. In International Symposium for "The Organisation and Management of Construction". Shaping Theory and Practice. Managing the Construction Project and Managing Risk; Langford, D.A., Retik, A., Eds.; CIBW: London, UK, 1996; Volume 65, pp. 95-104.

59. Zavadskas, E.K.; Turskis, Z.; Tamošaitienè, J.; Marina, V. Multicriteria selection of project managers by applying grey criteria. Technol. Econ. Dev. Econ. 2008, 14, 462-477. [CrossRef]

60. Turskis, Z.; Zavadskas, E.K.; Kutut, V. A model based on ARAS-G and AHP methods for multiple criteria prioritizing of heritage value. Int. J. Inf. Technol. Decis. Mak. 2013, 12, 45-73. [CrossRef]

61. Brauers, W.K.M.; Zavadskas, E.K. The MOORA method and its application to privatization in a transition economy. Control Cybern. 2006, 35, 445-469.

62. Brauers, W.K.M.; Zavadskas, E.K. Project management by MULTIMOORA as an instrument for transition economies. Technol. Econ. Dev. Econ. 2010, 16, 5-24. [CrossRef]

63. Keršulienè, V.; Zavadskas, E.K.; Turskis, Z. Selection of rational dispute resolution method by applying new Step-Wise Weight Assessment Ratio Analysis (SWARA). J. Bus. Econ. Manag. 2010, 11, 243-258. [CrossRef]

64. Zavadskas, E.K.; Turskis, Z.; Antuchevičienè, J.; Zakarevičius, A. Optimization of weighted aggregated sum product assessment. Elektron. Elektrotechnika 2012, 122, 3-6. [CrossRef]

65. Krylovas, A.; Zavadskas, E.K.; Kosareva, N.; Dadelo, S. New KEMIRA method for determining criteria priority and weights in solving MCDM Problem. Int. J. Inf. Technol. Decis. Mak. 2014, 13, 1119-1133. [CrossRef]

66. Zavadskas, E.K.; Mardani, A.; Turskis, Z.; Jusoh, A.; Nor, K.M. Development of TOPSIS method to solve complicated decision-making problems-An overview on developments from 2000 to 2015. Int. J. Inf. Technol. Decis. Mak. 2016, 15, 645-682. [CrossRef]

67. Balli, S.; Korukoglu, S. Operating system selection using fuzzy AHP and TOPSIS Methods. Math. Comput. Appl. 2009, 14, 119-130. [CrossRef]

68. Tian, G.; Zhang, H.; Feng, Y.; Wang, D.; Peng, Y.; Jia, H. Green decoration materials selection under interior environment characteristics: A grey-correlation based hybrid MCDM method. Renew. Sustain. Energy Rev. 2018, 81, 682-692. [CrossRef]

69. Olson, D.L. Comparison of weights in TOPSIS Models. Math. Comput. Model. 2004, 40, 721-727. [CrossRef] 
70. Karimi, A.P.; Mehrdadi, N.; Hashemian, S.J.; Bidhendi, G.R.; Moghaddam, R.T. Using the fuzzy TOPSIS and fuzzy AHP methods for wastewater treatment process selection. Int. J. Acad. Res. 2011, 3, 737-745.

71. Escrig-Olmedo, E.; Rivera-Lirio, J.M.; Muñoz-Torres, M.J.; Fernández-Izquierdo, M.Á. Integrating multiple ESG investors' preferences into sustainable investment: A fuzzy multicriteria methodological approach. J. Clean. Prod. 2017, 162, 1334-1345. [CrossRef]

72. Khoshnava, S.M.; Rostami, R.; Valipour, A.; Ismail, M.; Rahmat, A.R. Rank of green building material criteria based on the three pillars of sustainability using the hybrid multi criteria decision making method. J. Clean. Prod. 2018, 173, 82-99. [CrossRef]

73. Khan, M.I. Evaluating the strategies of compressed natural gas industry using an integrated SWOT and MCDM approach. J. Clean. Prod. 2018, 172, 1035-1052. [CrossRef]

74. Mavi, R.K.; Standing, C. Critical success factors of sustainable project management in construction: A fuzzy DEMATEL-ANP approach. J. Clean. Prod. 2018, 194, 751-765. [CrossRef]

75. Dursun, M.; Arslan, Ö. An Integrated Decision Framework for Material Selection Procedure: A Case Study in a Detergent Manufacturer. Symmetry 2018, 10, 657. [CrossRef]

76. Jaśkowski, P.; Sobotka, A.; Czarnigowska, A. Decision model for planning material supply channels in construction. Autom. Constr. 2018, 90, 235-242. [CrossRef]

77. Medineckiene, M.; Zavadskas, E.K.; Björk, F.; Turskis, Z. Multi-criteria decision-making system for sustainable building assessment/certification. Arch. Civ. Mech. Eng. 2015, 15, 11-18. [CrossRef]

78. Pan, N. Fuzzy AHP approach for selecting the suitable bridge construction method. J. Autom. Constr. 2008, 17, 958-965. [CrossRef]

79. Zavadskas, E.K.; Turskis, Z.; Bagočius, V. Multi-criteria selection of a deep-water port in the Eastern Baltic Sea. Appl. Soft Comput. 2015, 26, 180-192. [CrossRef]

80. Hashemkhani Zolfani, S.; Zavadskas, E.K.; Turskis, Z. Design of products with both International and Local perspectives based on Yin-Yang balance theory and SWARA method. Econ. Res.-Ekon. Istraživanja 2013, 26, 153-166. [CrossRef]

81. Jadidi, O.; Firouzi, F.; Bagliery, E. TOPSIS method for supplier selection problem. Int. J. Soc. Behav. Educ. Econ. Bus. Ind. Eng. 2010, 4, 2198-2200.

82. Polat, G.; Eray, E.; Bingol, B.N. An integrated fuzzy MCGDM approach for supplier selection problem. J. Civ. Eng. Manag. 2017, 23, 926-942. [CrossRef]

83. Sonmez, M.; Yang, J.B.; Holt, G.D. Addressing the contractor selection problem using an evidential reasoning approach. Eng. Constr. Archit. Manag. 2001, 8, 198-210. [CrossRef]

84. AGC of America. Qualifications Based Selection of Contractors; AGC of America: Arlington, VA, USA, 2001.

85. Sandquist, R.S. Qualifications-Based vs. Low-Bid Contractor Selection. 2007. Available online: http: //www.aia.org/aiaucmp/groups/ek_members/documents/pdf/aiap017687.pdf (accessed on 11 June 2018).

86. Yawei, L.; Shouyu, C.; Xiangtian, N. Fuzzy Pattern Recognition Approach to Construction Contractor Selection. Fuzzy Optim. Decis. Mak. 2005, 4, 103-118. [CrossRef]

87. Taylan, O.; Kabli, M.R.; Porcel, C.; Herrera-Viedma, E. Contractor Selection for Construction Projects Using Consensus Tools and Big Data. Int. J. Fuzzy Syst. 2018, 20, 1267-1281. [CrossRef]

88. Turskis, Z.; Zavadskas, E.K.; Antucheviciene, J.; Kosareva, N. A hybrid model based on fuzzy AHP and fuzzy WASPAS for construction site selection. Int. J. Comput. Commun. Control 2015, 10, 113-128. [CrossRef]

89. Zavadskas, E.K.; Turskis, Z.; Antuchevičienė, J. Selecting a contractor by using a novel method for multiple attribute analysis: Weighted Aggregated Sum Product Assessment with grey values (WASPAS-G). Stud. Inform. Control 2015, 24, 141-150. [CrossRef]

(C) 2019 by the authors. Licensee MDPI, Basel, Switzerland. This article is an open access article distributed under the terms and conditions of the Creative Commons Attribution (CC BY) license (http://creativecommons.org/licenses/by/4.0/). 